\title{
HUMAN RESOURCE MANAGEMENT IN THE CONTEXT OF INDUSTRY 4.0
}

\author{
Katarzyna PIWOWAR-SULEJ \\ Wroclaw University of Economics, Komandorska 118/120, 53-345 Wroclaw, Poland; \\ katarzyna.piwowar-sulej@ue.wroc.pl, ORCID: 0000-0002-4627-4344
}

\begin{abstract}
The purpose of the article is to answer the following research question: What will change in particular elements of Human Resource Management be in the context of Industry 4.0? To achieve the defined purpose, literature studies and empirical research (based on focus group interviews with HR specialists) were used. Such HRM issues as the future of jobs, competencies required from employees and technological progress in HRM are discussed in the subject literature. The paper indicates the need to analyze changes in relation to particular elements of HRM and different groups of employees. It also presents some controversial scenarios of HRM's future and indicates directions for further research.
\end{abstract}

Keywords: human resource management, Industry 4.0, Fourth Industrial Revolution.

\section{Introduction}

Something that most clearly distinguishes modernity from all preceding periods is the unbelievable dynamism (Giddens, 2001). Nowadays, we are dealing with a truly energized era of change in the world of technology introduced by the Industrial Revolution 4.0. The Fourth Industrial Revolution is a concept regarding the use of automation and both data processing and exchange, as well as the implementation of various new technologies that allow the creation of so-called cyber-physical systems and changes in manufacturing processes. It also concerns the digitization of production, where devices and technological systems are connected with each other, including via the Internet, and where large amounts of production data are analyzed. We can consider Industry 4.0 to be a conceptual aggregate that includes a number of new technologies - including the Internet of Things, cloud computing, Big Data analysis and artificial intelligence, as well as incremental printing, augmented reality or cooperating robots (Mychlewicz, and Piątek, 2017).

When one compares it with previous Industrial Revolutions, one can find dramatic differences between the fourth Industrial Revolution and the other three. In its scale, scope and complexity, the transformation will be unlike anything humankind has experienced before. 
The Fourth Industrial Revolution is "not merely a prolongation of the Third Industrial Revolution, but rather a new and distinct revolution" (NICVA, 2019, p. 4). It is introducing technologies that blur the lines between the physical, digital and biological spheres across all sectors. Technologies like artificial intelligence, nanotechnology, quantum computing, synthetic biology and robotics will all drastically supersede any digital progress made in the past 60 years and create realities that were previously unthinkable. Such profound realities will disrupt and change the business model of each and every industry (Hinton, 2018).

These changes apply to everyday life and ways of performing work. This because organizational systems do not exist without humans (Latham, 2017). Therefore, managing people (human resources management, HRM) can be considered the key management area. This includes such activities as recruitment and selection, training and development, HR appraisal (HR performance management), renumeration (compensation management) and HR flow (career management).

As Whysall, Owtram and Brittain (2019, p. 118) state, "the speed of technological change brought about by Industry 4.0 had created a significant gap between current capability of employees and the rapidly evolving requirements of their roles, prompting a need to consider new and more effective approaches to human resources development". The authors focused on engineers treated as knowledge workers. But one can state that there are more challenges in HRM related to Industry 4.0 than simply training and developing employees. They can be discussed after they are divided into the particular HR activities mentioned above.

The purpose of the article is to answer the following research question: What will change in particular elements of Human Resource Management be like in the context of Industry 4.0? To achieve the defined purpose, literature studies and empirical research were used. The project is financed by the Ministry of Science and Higher Education in Poland under the programme "Regional Initiative of Excellence" 2019 - 2022 project number 015/RID/2018/19 total funding amount 10721 040,00 PLN.

\section{Research methods}

The first research method that was used for the purpose of this article is literature studies. In a literature review, researchers describe, evaluate and clarify what is already known about the research area. The author used a stand-alone review (Easterby-Smith, Thorpe, and Jackson, 2015), in order to provide an overview and synthesis. A review of subject literature was carried out by analyzing the databases available in the Library of the Wroclaw University of Economics (including Web of Science and Scopus). Such keywords as "The Fourth Industrial Revolution", "Industry 4.0" and "Technological Innovation" were used in combination with "Human Resource Management" and "Labor Market". The focus was placed on academic papers 
(in Polish and English). Additionally, the author used the Google search engine in order to find business reports and articles about the analyzed phenomena.

The second research method was focus group interview. This method is rarely used by Polish researchers. Its most common application is in the area of marketing research (Drapikowska, Palczewska, 2013). The applied method involves acquiring qualitative data during an informal discussion on a specific topic, between selected persons. This conversation must relate to situations, objects or information that are known to the respondents (Litosseliti, 2005, p. 13). In accordance with Drapikowska \& Palczewska (2013, p. 74), in all definitions of a focus group interview it is emphasized that:

a) the group is small (from 6 to 10 people) and is relatively homogeneous,

b) the group is an informal gathering that has been deliberately chosen,

c) the group is run by a qualified moderator who uses certain methods and practices in order to obtain the respondents' true opinions,

d) the focus group does not produce quantitative information,

e) the purpose of a focus group interview is to record all the behaviors that accompany the respondents' answers.

The main advantages of the focus group technique are the relatively short time needed to gather relevant information and the opportunity to observe the dynamics of participants' attitudes and interaction between them.

In accordance with the methodological guidelines, three interviews focused on the same group of respondents, consisting of six people (HR specialists) were carried out in June and July 2019. The interviews were more than four hours long. This means that the author used extended, mini focus group interviews with experts. The study was conducted - in accordance with the British style, in natural conditions, and the author of this article played the role of moderator. The natural environment, i.e., the moderator's home, stimulated the openness of respondents.

Due to methodological shortcomings, including the unrepresentativeness of the sample, the value of a focus group interview has been repeatedly questioned. However, it was found that this method may prove to be very useful during the conceptualization phase of any study, and through its application, the researcher may get help in formulating hypotheses, research problems or conducting a pilot study (Drapikowska, Palczewska, 2013). Focus group interviewing offers an opportunity to explore issues that are not well understood or where there is little prior research on the topic (Nyumba, et al., 2018), as in the case of Poland. The detailed purpose of the interviews was to collect information about the expected changes in HRM activities related to the above-mentioned HRM elements. It is worth mentioning that different reports show that achieving the level of the Third Industrial Revolution is still a challenge for Poland (Iwański, and Gracel, 2016; Siemens, 2016; Low Business Quality, 2018). Therefore, it is valuable to discover how Polish HR specialists perceive the changes. 


\section{Results of literature studies}

The problems and influence of the Fourth Industrial Revolution are being touched on up in the subject literature. The existing publications usually focus only on development of modern technologies and on some aspects of technological changes. Liao et al. (2017) state that in current research, attention has been paid to the concept of IT integration (e.g., vertical, company-wide and horizontal connection of IT systems). It is clear that standardization of processes and resource productivity are the areas that attract most of the research efforts.

The analysis of journal databases indicates that the creation of demand for labor is the most frequently discussed problem, combining technological innovation with the labor market. Publications often list innovation as one of many factors influencing the demand for labor. It is worth mentioning that J. M. Keynes described technological unemployment as unemployment caused by the discovery of ways to economize the use of labor outrunning the pace at which new uses for labor can be found (for more see: Rifkin, 1995). In different reports one can find that the number of jobs for unqualified people will be reduced in the future, whereas the demand for highly competent people should increase (Piwowar-Sulej, 2018). According to McKinsey, due to the vast advancements in automation, up to 375 million workers may need to change their occupational category and up to 800 million individuals may be displaced by automation by 2030 (Hinton, 2018). However, publications from the last ten years, more often than in the literature published earlier, focus on a positive approach to the "technology - labor market" relationships. For example, Ugur, Churchill and Solomon (2018) discuss the correlation of technological innovation on employment, showing that the impact of innovation on employment growth is positive, if small and highly non-uniform. Furthermore, Degryse (2016) points out that there are also less qualified jobs with the least risk of automation, e.g., social workers and hairdressers.

Moreover, one can find three alternative scenarios of the technological impact on the future workforce (McGowan, 2018). In scenario one, automation will act as an optimizer. Ideally, robotics or artificial intelligence will serve two purposes: to expand the enterprise and to serve the workforce. If companies use automation and advanced data for these ends, Industry 4.0 will optimize the future of work, to improve rather than replace employment conditions and opportunities. Therefore, the subjects of academic interest cover such HRM issues as preparing employees for new challenges related to the technological changes (Piwowar-Sulej, 2018a; Whysall, Owtram, and Brittain, 2019). Employers should, hence, focus on the competencies required to achieve their business objectives so as to remain competitive and agile, and this requires them to ensure their employees undergo the necessary training to fill these competency gaps. In addition, employees need to acquire competencies "on demand" in order to adapt to their changing roles and responsibilities (Hinton, 2018). 
Hecklau et al. (2017) conducted a meta-study-analysis of future competencies in Industry 4.0. A summary of their findings is presented in Table 1 with the focus on competencies that were mentioned in at least three studies.

Table 1.

The most important social, methodological, domain-related and personal competencies for Industry 4.0

\begin{tabular}{|c|c|c|}
\hline $\begin{array}{c}\text { Type of } \\
\text { competency }\end{array}$ & $\begin{array}{c}\text { Particular } \\
\text { competencies }\end{array}$ & Explanation \\
\hline Social & $\begin{array}{l}\text { Communication \& } \\
\text { Co-operation }\end{array}$ & $\begin{array}{l}\text { Service-orientation demands good listening and presentation skills. } \\
\text { Increasing virtual work requires sufficient virtual communication } \\
\text { skills. }\end{array}$ \\
\hline \multirow[t]{3}{*}{ Methodological } & $\begin{array}{l}\text { Analytical } \\
\text { competence }\end{array}$ & $\begin{array}{l}\text { Structuring and examining large amounts of data and complex } \\
\text { processes is becoming mandatory. }\end{array}$ \\
\hline & $\begin{array}{l}\text { Complex problem } \\
\text { solving }\end{array}$ & $\begin{array}{l}\text { Employees must be able to identify sources of errors and be able to } \\
\text { improve processes. }\end{array}$ \\
\hline & Decision making & $\begin{array}{l}\text { Responsibilities are shifted to the process level. More decisions have } \\
\text { to be made independently. }\end{array}$ \\
\hline Personal & Willingness to learn & $\begin{array}{l}\text { Changing situations do not create any problems. Failure can be } \\
\text { learnt. Within a reasonable period of time, new knowledge and skills } \\
\text { can be obtained that enable the person to perform other tasks. }\end{array}$ \\
\hline \multirow[t]{5}{*}{ Domain } & Digital networks & $\begin{array}{l}\text { Working in a highly globalized and intertwined value chain requires } \\
\text { knowledge networks. }\end{array}$ \\
\hline & Digital security & $\begin{array}{l}\text { Virtual work on servers or platforms obligates employees to be } \\
\text { aware of cyber security. }\end{array}$ \\
\hline & Coding competence & $\begin{array}{l}\text { The growth of digitized processes creates a higher need for } \\
\text { employees to understand and write code. }\end{array}$ \\
\hline & $\begin{array}{c}\text { Process } \\
\text { understanding }\end{array}$ & $\begin{array}{l}\text { Higher process complexity demands a broader and deeper process } \\
\text { understanding, thinking and acting in networked and cross-cutting } \\
\text { processes. }\end{array}$ \\
\hline & $\begin{array}{l}\text { Interdisciplinary } \\
\text { competence }\end{array}$ & $\begin{array}{l}\text { The increasing complexity of work requires multiple competence } \\
\text { sets and knowledge. }\end{array}$ \\
\hline
\end{tabular}

Source: based on Hecklau et al. (2017, p. 168-169).

In scenario two, cooperation will replace automation as a priority for Industry 4.0. In this scenario, the workforce will have a voice. This scenario encourages organizations to engage the workforce, not alienate it. It envisions building on best practices from the technology companies that actually produce some of the tools that could disrupt the workforce. It engages labor organizations and governments to develop new workforce strategies together.

Finally, in scenario three, the digital transformation will lead workforce transformation. Automation will find its own level of expertise. That level might exceed human ability in many cases, but human ability need not be devalued. In scenario three, there is a strong argument that specific human skill sets will become even more important in Industry 4.0. As Trompisch (2017) states, the advancing use of Industry 4.0 technologies will not lead to a complete automation and a resulting competitive struggle between humans and machines, but it raises the question of the best possible cooperation between humans and machines.

New opportunities for IT tool implementation in HR processes are discussed in the subject literature as well (e.g., Onik, Miraz, and Kim, 2018). According to Sivathanu and Pillai (2018), emerging technologies such as the Internet-of-Things and artificial intelligence will automate 
most of the HR processes - changing HR services into a Smart HR concept. This would allow HR departments to play a more strategic role. Table 2 presents how particular elements of HRM are supported by traditional IT and how it will be supported by ubiquitous computing technologies. A traditional technology is characterized by interactions based on IT devices that assume a fixed physical relationship between the employee and their work environment, while ubiquitous computing technology is characterized by interactions based on sensors and devices embedded in products, processes, individuals and buildings, and on unlimited access to computing, data and communication networks from any location at any time. Context-aware technology is alert to an employee's physical surroundings, as well as his/her cognitive and social states, and takes decisions in a proactive fashion, anticipating the employee's needs.

Table 2.

Approaches to particular HRM elements supported by traditional and ubiquitous computing technologies

\begin{tabular}{|c|c|c|}
\hline $\begin{array}{c}\text { HRM } \\
\text { elements }\end{array}$ & $\begin{array}{c}\text { Supported by traditional } \\
\text { technology }\end{array}$ & $\begin{array}{c}\text { Supported by ubiquitous } \\
\text { computing }\end{array}$ \\
\hline $\begin{array}{l}\text { Recruitment } \\
\text { and selection }\end{array}$ & $\begin{array}{l}\text { It is based on attracting and selecting } \\
\text { capable employees through media } \\
\text { advertising, broadcast postings, yield } \\
\text { pyramids, staffing graphs, onsite } \\
\text { testing, face-to-face interviewing. }\end{array}$ & $\begin{array}{l}\text { It is based on individuals and companies } \\
\text { exchanging continuous data through social media, } \\
\text { mobile devices, electronic boards and other } \\
\text { means that create a mutual awareness to transmit } \\
\text { the right message to the right person at the right } \\
\text { time. }\end{array}$ \\
\hline HR Appraisal & $\begin{array}{l}\text { Periodic performance appraisals are } \\
\text { based on historical tracking, behavioral } \\
\text { checklists, graphic rating scales and } \\
\text { behaviorally anchored rating scales. }\end{array}$ & $\begin{array}{l}\text { It is based on instant and on-demand appraisal, } \\
\text { guidance, support and alerts enabled by digital } \\
\text { traces of embedded and context-aware } \\
\text { technologies tracking work, as well as of roaming } \\
\text { employees. Software manages job evaluation. }\end{array}$ \\
\hline $\begin{array}{l}\text { Training and } \\
\text { development }\end{array}$ & $\begin{array}{l}\text { New employees learn from } \\
\text { experienced ones through in-house, } \\
\text { face-to-face instruction, lectures, } \\
\text { simulations or programmed instruction, } \\
\text { as well as through apprenticeship } \\
\text { programs whose focus is on-the-job } \\
\text { training. }\end{array}$ & $\begin{array}{l}\text { It is based on access to instantly available } \\
\text { knowledge, on-demand development of skills and } \\
\text { intellectual abilities through boundaryless } \\
\text { delivery of instruction materials, virtual reality } \\
\text { simulations, asynchronous training, educational } \\
\text { games, chat rooms and knowledge-management } \\
\text { systems. }\end{array}$ \\
\hline Renumeration & $\begin{array}{l}\text { Pay systems are based on manual job } \\
\text { evaluation, pay-survey analyses } \\
\text { spreadsheets to analyze bonus and } \\
\text { commission structures. }\end{array}$ & $\begin{array}{l}\text { Software manages pay-survey analyses, complex } \\
\text { bonus and commission structures, reports, and } \\
\text { analytics. Pay is based on specific work output. }\end{array}$ \\
\hline HR flow & $\begin{array}{l}\text { It is based on a joint effort of employee } \\
\text { and company in matching career goals } \\
\text { through career-path planning, in-house } \\
\text { library, intranets for career self-service } \\
\text { and online self-assessments. }\end{array}$ & $\begin{array}{l}\text { It is based on employee-centric career } \\
\text { arrangements in recognition of the fact that wants } \\
\text { and needs vary over the span of an individual's } \\
\text { career. Untethered workers are able to perform } \\
\text { tasks anywhere at any time. }\end{array}$ \\
\hline
\end{tabular}

Source: based on (Cascio, and Montealegre, 2016, pp. 366-367).

According to the latest forecasts, the global HR software market is expected to grow in the years to come by $2.4 \%$ annually and to reach a value of 9.2 billion $\$$ by 2020 (Marketanalysis.com, 2014). The use of IT tools not only enables companies to build new more efficient - architecture of HR processes, but also to meet employees' expectations. New generations of employees (called "Z", "C" or "www") are coming. They have enormous expectations when it comes to companies' online presence and people's responsiveness. 


\section{Findings from empirical research and discussion}

It is difficult to interpret the material collected due to the non-standardized nature of the focus group method. First, it is necessary to make a formative interpretation. This was done by preparing a list of discussed topics, identifying and naming them. Then the author identified common points in the discussion (similar opinions or experience) and finally typologized them. The findings from empirical research are shown in Table 3.

The first result of empirical study is the need to differentiate employees. One should not discuss the changes in HRM without taking into consideration different types of work and positions in an organization. The influence of Industry 4.0 will not be equal in relation to low skilled, medium skilled and highly skilled employees. For example, these days, only low skilled job candidates deliver their printed CVs to potential employers, and it will change. Moreover, companies are more likely to invest in attractive IT solutions when it comes to their key employees.

The point of view depends on the level of technological maturity of the current workplace, the region or the country. It is hard to imagine a digital future while dealing on an everyday basis with printed documents and phone calls or living in a place where problems with Internet access occur. Therefore, the common opinions of the respondents which are shown in Table 3 are based on their current experience, information from the media and own imagination.

Table 3.

Changes in HRM elements related to Industry 4.0 - results of focus group interviews

\begin{tabular}{|c|c|c|c|}
\hline $\begin{array}{l}\text { Element of } \\
\text { HRM } \\
\end{array}$ & $\begin{array}{l}\text { Low skilled } \\
\text { employees }\end{array}$ & $\begin{array}{c}\text { Medium skilled } \\
\text { employees }\end{array}$ & $\begin{array}{c}\text { Creative jobs, highly skilled } \\
\text { specialists, managers }\end{array}$ \\
\hline $\begin{array}{l}\text { Recruitment } \\
\text { and selection }\end{array}$ & $\begin{array}{l}\text { - No printed CVs } \\
\text { - Broader utilization of } \\
\text { modern technologies }\end{array}$ & $\begin{array}{l}\text { - Broader utilization of } \\
\text { modern technologies } \\
\text { - Command of modern } \\
\text { technologies as job } \\
\text { requirement }\end{array}$ & $\begin{array}{l}\text { - Increase in gamification-based } \\
\text { solutions } \\
\text { - Artificial intelligence used in } \\
\text { Internet searches and delivering } \\
\text { HR specialists obtain } \\
\text { multidimensional information } \\
\text { about candidates }\end{array}$ \\
\hline $\begin{array}{l}\text { Training and } \\
\text { development }\end{array}$ & $\begin{array}{l}\text { - Training in the use of } \\
\text { new technologies }\end{array}$ & $\begin{array}{l}\text { - Training in the use of } \\
\text { new technologies } \\
\text { - Training in Virtual } \\
\text { Reality }\end{array}$ & $\begin{array}{l}\text { - Training in the use of new } \\
\text { technologies } \\
\text { - Training in Virtual Reality } \\
\text { - Knowledge "on demand" - } \\
\text { artificial intelligence used in order } \\
\text { to deliver customized knowledge }\end{array}$ \\
\hline HR appraisal & $\begin{array}{l}\text { - Digital control and } \\
\text { measurement of job } \\
\text { performance } \\
\text { - Real-time } \\
\text { performance data for } \\
\text { both employers and } \\
\text { employees }\end{array}$ & $\begin{array}{l}\text { - Digital control and } \\
\text { measurement of job } \\
\text { performance } \\
\text { - Real-time performance } \\
\text { data for both } \\
\text { employers and } \\
\text { employees }\end{array}$ & $\begin{array}{l}\text { - Faster recognition of the results of } \\
\text { conceptual, creative work }\end{array}$ \\
\hline
\end{tabular}


Cont. table 3.

\begin{tabular}{|c|c|c|c|}
\hline Remuneration & $\begin{array}{l}\text { - } \text { More cafeteria } \\
\text { remuneration }\end{array}$ & $\begin{array}{l}\text { - } \text { More cafeteria } \\
\text { remuneration. New } \\
\text { line IT systems for } \\
\text { building an } \\
\text { individualized total } \\
\text { compensation package } \\
\text { - Bitcoin }\end{array}$ & $\begin{array}{l}\text { - "Less cash-based rewards, more } \\
\text { freedom/choice" } \\
\text { - More cafeteria remuneration } \\
\text { - New line IT systems for building } \\
\text { an individualized total } \\
\text { compensation package } \\
\text { - Bitcoin } \\
\text { - Combination of data "on demand" } \\
\text { - artificial intelligence used in } \\
\text { order to deliver market reports } \\
\text { about compensation and benefits } \\
\text { for different positions }\end{array}$ \\
\hline HR flow & $\begin{array}{l}\text { - In the direction of } \\
\text { "less manual work, } \\
\text { more steering" } \\
\text { (e.g., in nursing) }\end{array}$ & $\begin{array}{l}\text { - In the direction of new } \\
\text { positions and new jobs } \\
\text { (e.g., self-driving car } \\
\text { mechanic; Internet-of- } \\
\text { Things-based } \\
\text { (individualized) } \\
\text { equipment repair } \\
\text { person) }\end{array}$ & $\begin{array}{l}\text { - Broad individualization of careers } \\
\text { - In the direction of new positions } \\
\text { and new jobs (e.g., drone manager } \\
\text { instead of fleet manager, e-coach) }\end{array}$ \\
\hline
\end{tabular}

Source: own empirical research.

As indicated before, the positive approach which links people with modern technologies is becoming more and more popular in the subject literature. The respondents during the focus group interviews also created a rosy vision of the future with technology supporting people regardless of their position in the organizational hierarchy. For example, low skilled employees will perform less manual work and HRM will be focused on developing their skills related to the use of new technologies.

HR specialists strongly expressed their requirements in relation to HR appraisal processes. Real-time performance data for both employers and employees is needed and they hope that the future will bring appropriate solutions. They also imagine that in the future, IT systems will collect and analyze data from many sources related to the level of compensation and types of benefits offered to particular positions or jobs. This opinion is consistent with the view presented by W. F. Cascio and R. Montealegre. However, it is difficult to imagine tools that help control creative or conceptual work. Therefore, modern technologies should only speed up the delivery of feedback about results after implementing the employees' ideas.

One can find in academic and business literature the view that the employees are now more focused on purpose than ever before. Less driven by financial motivation, the new workforce is open to compensation that is not only about money. They would like to have an interesting, flexible and meaningful job and managers who will want to listen to their ideas (Schroth, 2019). They are "less interested in becoming rich than in gaining the experiences that will help them lead a life that is richer". At this point it should be mentioned that such opinions are based on research conducted on well-educated people. In business practice, there are still low positions where people do not earn much and money is important to them. That is why the traditional money-based remuneration approach will still exist. However, IT systems will help manage an individualized total compensation package for medium and highly skilled employees. 
Some of the above-presented opinions are new and controversial. For example, the use of Bitcoin (cryptocurrency, a form of electronic cash) in the area of compensation management needs first of all to have its legitimacy. In turn, established artificial intelligence used in Internet searches and providing HR specialists with information about highly skilled candidates raises ethical concerns.

\section{Conclusions}

The subject literature provides a number of descriptions of the new reality, addressing various aspects of the incoming changes, including issues related to HRM. The future of jobs, the competencies required from employees and technological progress in HRM are being discussed. This article contributes to the knowledge about specific conditions of HRM in modern enterprises. It focuses on activities related to particular HRM elements and employees with different qualifications.

The paper also provides some practical implications. Having in mind the above presented ethical issues, it is worth emphasizing that not only the rapid development of IT, but also managers (including HR professionals) have influence on the shape and pace of changes in the local and global scale (especially in global corporations). They should be well prepared for changes and aware of the advantages and disadvantages of applying different solutions. Furthermore, they should take into account, as indicated in this study, the level of technological maturity of the current workplaces, the region or the country and differences between qualifications.

The author is aware of the limitations resulting from the methodology of this research. However, the presented findings suggest directions for future research. The need occurs to discuss HRM changes whilst taking into account other differentiators of employees, e.g., organization of their work (individual vs. team work; traditional vs. tele-employees) and type of employment (traditional employment vs. contract with freelancers). Moreover, such factors as the legal system and culture play an important role in this area. It would also be interesting to conduct comparative research with HR specialists from different countries. 


\section{References}

1. Degryse, Ch. (2016). Digitalisation of the economy and its impact on labour markets, Brussels: European Trade Union Institute.

2. Drapikowska, B., and Palczewska, M. (2013). Zogniskowany wywiad grupowy oraz techniki projekcyjne jako przykłady jakościowych empirycznych metod badawczych stosowanych w naukach społecznych, Obronność. Zeszyty Naukowe Wydziału Zarządzania i Dowodzenia Akademii Obrony Narodowej, 3(7), 71-86.

3. Easterby-Smith, M., Thorpe, R., and Jackson, P.R. (2015). Management and Business Research. London: Sage Publication.

4. Giddens, A. (2001). Nowoczesność i tożsamość. „Ja” i społeczeństwo w epoce późnej nowoczesności. Warszawa: PWN.

5. Hecklau, F. et al. (2017). Human Resources Management: Meta-Study - Analysis of Future Competences in Industry 4.0. Proceedings of the International Conference on Intellectual Capital, Knowledge Management \& Organizational Learning, 163-174.

6. Hinton, S. (2018). How The Fourth Industrial Revolution Is Impacting The Future of Work, Forbes, Oct 19, Retrieved from https://www.forbes.com/sites/theyec/2018/10/19/how-thefourth-industrial-revolution-is-impacting-the-future-of-work/\#7de0ddeb65a7, 2019.07.15.

7. Latham, J. (2019). Without people organizational system don't exist. http://johnlatham.me/ psychology-stakeholders, 2019.07.20.

8. Law Business Quality (2018). Druzgocacy raport: czwarta rewolucja przemystowa ominęła polskie fabryki?, http://magazynlbq.pl/druzgocacy-raport-czwarta-rewolucjaprzemyslowa-ominela-polskie-fabryki/, 2019.07.13.

9. Liao, Y. et al. (2017). Past, present and future of Industry 4.0 - a systematic literature review and research agenda proposal. International Journal of Production Research, 55(12), 36093629. doi: 10.1080/00207543.2017.1308576.

10. Litosseliti, L. (2005). Using focus groups in research, Cornwall: MPG Books Ltd.

11. MarketAnalysis.com (2014). Human Resources (HR) Software Market Forecast 20152020, Tabular Analysis (2014), http://www.marketanalysis.com/?p=338, 2019.07.01.

12. McGowan, R. (2018). Here are 3 alternative visions for the future of work. World Economic Forum, 18 Dec. 2018, Retrieved from https://www.weforum.org/agenda/2018/12/ alternative-future-work-opportunity-fear-industry/, 2019.07.11.

13. Mychlewicz, C., and Piątek, Z. Od Industry 4.0 do Smart Factory, Poradnik menedżera $i$ inżyniera. Retrieved from https://publikacje.siemens-info.com/pdf/76/Od\%20Industry \%204.0\%20do\%20Smart\%20Factory.pdf , 2019.06.28.

14. NICVA (2019). The Impacts of the Fourth Industrial Revolution on Jobs and the Future of the Third Sector, https:/www.nicva.org/sites/default/files/d7content/attachments-articles/ the_impact_of_the_4th_industrial_revolution_on_jobs_and_the_sector.pdf, 2019.07.12. 
15. Nyumba, T.O., Wilson, K., Derrick, Ch.J., and Mukherjee, N. (2018). The use of focus group discussion methodology: Insights from two decades of application in conservation, Methods in Ecology and Evolution, 9, 20-32, doi:10.1111/2041-210X.12860.

16. Onik, M.M.H., Miraz, M.H., and Kim, C.S. (2018). A recruitment and human resource management technique using Blockchain technology for Industry 4.0. Proceedings of the Smart Cities Symposium (SCS-2018), 11-16, doi: 10.1049/cp.2018.1371.

17. Piwowar-Sulej, K. (2018). Human Resources Management in the Industrial Revolution 4.0: General and Polish Perspective. Double-blind peer-reviewed proceedings of the international scientific conference Hradec Economic Days, 8(2), 179-187.

18. Piwowar-Sulej, K. (2018a). Employee 4.0 from the competitive perspective. Studia i Prace WNEiZ US, 52/3, 121-129, doi: 10.18276/sip.2018.52/3-12.

19. Rifkin, J. (1995). The End of Work: The Decline of the Global Labour Force and the Dawn of the Post-market Era. New York: Putnam Publishing Group.

20. Schroth, H. (2019). Are You Ready for Gen Z in the Workplace? California Management Review, 61(3), 5-18.

21. Siemens (2016). Smart Industry Polska 2016. Raport z badań, Retrieved from https://publikacje.siemensinfo.com/pdf/123/Raport\%20Smart\%20Industry\%20Polska\%20 2016.pdf, 2019.07.12.

22. Sivathanu, B., and Pillai, R. (2018). Smart HR 4.0 - how industry 4.0 is disrupting HR. Human Resource Management International Digest, 26(4), 7-11.

23. Trompisch, P. (2017). Industrie 4.0 und die Zukunft der Arbeit [The implications of Industry 4.0 on the future of work]. Elektrotechnik und Informationstechnik, 134(7), 370373.

24. Ugur, M., Churchill, S.A,. and Solomon, E. (2018). Technological innovation and employment in derived labour demand models: a hierarchical meta-regression analysis. Journal Of Economic Surveys, 32(1), 50-82, doi: 10.1111/joes.12187.

25. Whysall, Z., Owtram, M., and Brittain, S. (2019). The new talent management challenges of Industry 4.0. Journal of Management Development, 38(2), 118-129, doi:10.1108/JMD06-2018-0181. 